\title{
The changing face of contemporary translation studies through polydisciplinary lenses: Possibilities and caveats
}

\author{
Klaudia BEDNÁROVÁ-GIBOVÁ
}

\author{
University of Presov \\ Presov, Slovak Republic
}

\begin{abstract}
This paper offers a meta-reflection of contemporary translation studies (TS) through tracing its polydisciplinary tensions which are approached as both formative forces as well as hindrances. Taking a form of an argumentative essay employing the methods of a reflexive introspection, synthesis and evaluation, the principal aim is to address the potentials and controversies in presentday TS which are connected to its polydisciplinarity. This is a result from the aftermath of Snell-Hornby's integrated approach (1988/1995), TS's cultural and ideological turns as well as cognitive, sociological, anthropological, technological and economic twists. Four major strands of the consequences of the polydisciplinarity in TS are addressed: (a) the clash between the focus on the epistemological core of TS as an antidote to the expanding boundaries of the meta-discipline and embrace of reciprocal interdisciplinarity; (b) the tension between academia as 'Ivory Tower' and practice-minded language industry; (c) the diffusion of the outer boundaries of TS and erasure of its inner boundaries; (d) a multitude of different conceptualizations of TS foregrounding either the abstract or practical. Following TS's inward orientations, two outward turns are suggested, i.e. promoting its relevance to other disciplines and reaching out to translation practice, in tune with Zwischenberger's approach (2019). A continuation of the outward turns may be seen in Gentzler's post-translation studies focusing on the study of pre-translation culture and after-effects of translation in the target culture. Although the paper does not tend to conceptual extremes, it suggests that authentic transdisciplinary TS should be mindful of a constructive and mutually enriching dialogue with donor disciplines and interlacement between theory and practice, with a focus on realworld issues, becomes imperative in order to make TS viable.
\end{abstract}

Keywords: translation studies. paradigmatic shifts, polydisciplinarity, inward turn, outward turn, post-translation studies

\section{For citation:}

Bednárová-Gibová, Klaudia. 2021. The changing face of contemporary translation studies through polydisciplinary lenses: Possibilities and caveats. Russian Journal of Linguistics 25 (2). 462-477. DOI: https://doi.org/10.22363/2687-0088-2021-25-2-462-477 


\title{
Динамика современных переводческих исследований сквозь призму полидисциплинарности: проблемы и перспективы
}

\author{
Клаудиа БЕДНАРОВА-ГИБОВА
}

\author{
Прешовский университет \\ Прешов, Республика Словакия
}

\begin{abstract}
Аннотация
В статье обсуждается состояние современного переводоведения, обусловленное его полидисциплинарностью, которая, с одной стороны, играет созидательную роль, а с другой - создает определенные сложности. Цель данного аргументативного обзора - рассмотреть перспективы и противоречия современных переводоведческих исследований, связанные с полидисциплинарностью, используя методы рефлексивной интроспекции, синтеза и оценки. Эта трактовка основана на интегративном подходе М. Снелл-Хорнби (Snell-Hornby 1988/1995), а также ряде культурных, идеологических, когнитивных, антропологических, технологических и экономических факторов. В статье затрагиваются четыре проблемы, обусловленные полидисциплинарностью в переводоведении: а) столкновение между гносеологическим ядром переводоведческой теории, противостоящим расширению границ метадисциплины и интердисциплинарностью; б) противоречие между научным сообществом - «Башней из слоновой кости» - и повседневной лингвистической практикой; в) размывание внешних и стирание внутренних границ в теории перевода; г) наличие множественных подходов к переводоведению, выдвигающих на первый план его абстрактные либо прикладные аспекты. С учетом внутренних установок в теории перевода предлагаются два возможных пути развития: утверждение значимости перевода для других дисциплин и внедрение его достижений в практику перевода в соответствии с подходом К. Цвишенбергер (Zwischenberger 2019). Продолжение развития можно увидеть в постпереводческих исследованиях Э. Гентцлера (Gentzler 2017), направленных на изучение допереводческой культуры и влияние результатов перевода на культуру языка перевода. Не будучи склонным к крайностям, автор статьи, тем не менее, утверждает, что истинная междисциплинарность переводоведения требует конструктивного и взаимообогащающего диалога с другими дисциплинами, а также взаимосвязи теории и практики, с учетом реальной действительности, что сделает теорию перевода жизнеспособной.
\end{abstract}

Ключевые слова: теория перевода, парадигматические сдвиги, полидисциплинарность, внутреннее изменение, внешнее изменение, постпереводческие исследования

\section{Для цитирования:}

Bednárová-Gibová K. The changing face of contemporary translation studies through polydisciplinary lenses: Possibilities and caveats. Russian Journal of Linguistics. 2021. Vol. 25. № 2. P. 462-477. DOI: https://doi.org/10.22363/2687-0088-2021-25-2-462-477

\section{Introduction}

Considering a discipline's meta-reflection after more than four decades of its vibrant development, it would be no understatement to say that translation studies (TS), as now progressively institutionalized academic field of study related to translation theory and practice, has undergone changing trends and paradigmatic shifts over the past few decades. Since its formal beginnings in western Europe in 
the 1970s when the term translation studies was neologistically coined by James Holmes and presented in his now famous speech "The Name and Nature of Translation Studies" (1988/2004), TS has evolved from an overshadowed sub-branch of contrastive linguistics and comparative literature into a multidiscipline interwoven with many other fields (such as cognitive linguistics, cultural studies including gender and postcolonial studies, philosophical strands of enquiry, sociology, psychology, creative writing and so on), thus creating fertile ground for its polydisciplinarity.

It is evident that TS can no longer be conceptualized as a self-contained unidimensional field, but should be seen as "a composite, interdisciplinary network of data, methods, theories and hypotheses" (Hodgson 2008 in Shadman, Khoshsaligheh and Pishghadam 2019: 29). It has come to represent "a cluster concept with an open definition" (Tymoczko 2005 in ibid.), and it is precisely this open-ended character coupled with an absence of sharp boundaries which enables TS to adjust to changing cultural conditions, social functions and challenges as well as emerging technological innovations that have shaken its textual ground.

\section{Subject of research, aims and methods}

With regard to a conceptual-structural architecture of this argumentative paper, it is my aim to first, delve into the more recent past of TS in order to identify its contemporary research scenarios and perhaps more importantly, its tantalizing research consequences, in methodological compliance with so-called turns or 'shifting viewpoints', to borrow from Snell-Hornby (2006), that have shaped the courses of its development. By drawing attention to the selected strands of TS, it is my desideratum to highlight the recent changes in the status of TS that make it a true 'meta-hybrid' (Bednárová-Gibová 2018) in postmodernist terms, which also has repercussions on what translation is (or rather, is not) nowadays. Second, it is my aim to venture to address some potentials and even more controversies in present-day TS which are related to its polydisciplinarity. Third, in connection with the transdisciplinary meta-turn of TS, this paper aims to discuss the future directions of TS with a particular emphasis on post-translation studies as a strong potential 'motion vector' (Sdobnikov 2019).

It is my overarching aspiration to raise questions about the present state of the multidiscipline under discussion. At the same time, I wish to point out some risks being left behind by the profusion of innovations emerging from this, I dare to claim, at times disconcerting polydisciplinarity. Seeking unifying moments in this unfolding conceptual-reflexive quest, it is my effort to emphasize major tendencies, reified as recurrent themes (seen through a lens of narratology), traceable in the extant approaches in order to create a new space for a translatological reflection of the raised issues. Current theoretical and methodological practices in TS have the potential to diversify how its developmental paths are understood, but they have so far lacked considerable attention across the meta-discipline. Following one of the three-tiered yet interlaced aims, the following research question has been posed in 
the present paper: what potentials and caveats does contemporary TS, also with regard to its foreseeable future, hold for players of both academia as well as the practically-minded language industry? As is evident from the preceding, the methods of reflexive analysis, synthesis and evaluation will have been used to serve the stated research aims.

\section{The sources of present-day polydisciplinarity in translation studies}

Before identifying the hybrid sources of present-day polydisciplinarity of TS, I consider it important to draw attention to Snell-Hornby's (1988/1995) integrated approach. This was instrumental in crossing the gaping chasm between linguistic and literary methods in TS by integrating insights from a host of other disciplines such as e.g. ethnology, psychology, cultural history, philosophy, sociology and so forth, for the first time ever, as El-dali (2011) argues.

Looking for possible parallels, the integrated approach as an antidote in TS could be likened to some extent to the much discussed 'lang-lit problem' (Leech and Short 1981/2007; Leech 2008) in linguistics when it divided linguists in two opposing camps advocating mutually exclusive stances as to whether or not literary studies should be incorporated into linguistic models. With a view to TS, Chesterman (2007) does not approve of the, in his own words, "artificial" linguistic and cultural divide, but advocates four major complementary approaches in contemporary research, that is linguistic, cultural, cognitive and sociological. This suggests that contemporary TS research cannot be strictly entrenched only within one restrictive "research mindscape", as I metaphorically call ontological points of departure for research, because interdisciplinary contacts and overlaps between the individual approaches have been gaining momentum more than ever.

The renunciation of the linguistics-stage of TS, redolent of the by-gone Catfordian era, has been symptomatic of western TS especially since the 1980s when TS seemed overwhelmed by the cultural turn, as propounded by Bassnett and Lefevere (1990), with translation typifying a 'cross-cultural event' (Snell-Hornby 1988/1995). The growing emphasis on the cultural aspects of the translation process marked a move away from the 'equivalence paradigm' (Gambier 2016), based on a linguistic approach to a translatum and led to the prioritization of functionalist orientations in translation emphasizing the translation skopos, needs and expectations of prospective target text recipients, foregrounding the "parameters of a communicative situation [that] determine the translation goal" (Sdobnikov 2019: 299), downplaying the source text.

In her ground-breaking book fiercely advocating interdisciplinarity, SnellHornby (2006) critically dwells on the empirical and globalization turns of 1990s, highlighting the importance of doing practical research in TS and the rising significance of technological and advertising determinants as well as new Englishes on translation phenomena, and eventually proposes a 'translation turn' at the turn of the millennium. As an aftermath of the linguistic and cultural turns, WingKwong Leung (2006) identifies an 'ideological turn' with a sharpened focus on the 
ideological importance of the act of translation envisaged as an instrument of ideological resistance through the method of critical discourse analysis.

According to the study by Bednárová-Gibová (2018), more recent avenues of research in contemporary TS can be organized along cognitive, sociological, anthropological, technological and economic lines. Whereas the cognitivelyoriented line of enquiry homes in cognition-related issues of the translation process research affecting the integration of cognitive paradigms and promotion of neuroscientific research, the sociological lens enables a participant-oriented research with translators as socially constructed agents. Departing from deepening social implications of translation, Wolf (2014) promotes what she dubs an 'activist turn' and zooms in on a range of social, cultural, ideological and political aspects which have an influence on translators' choices, construing them as agents of resistance and emancipation. Zeroing in on the essentially anthropological concept of performance, now applied to the translator's processuality in the wake of the forward-moving sociology of translation, Wolf (2017) upholds at the same time a 'performance turn', although not fully acknowledged yet in TS. Through its sociocultural and political interlacements, the performance turn marks a shift away "from words, artefacts and textual research towards the understanding of the performative processes of cultural practices" (Wolf 2017: 30) in which meaning is constructed and subsequently transcended on the basis of social action.

The technological twist in TS, as already reported by Cronin (2010), shedding fresh light on recent fashionable translation practices like fansubbing, crowdsourcing, and localization (among many other things), opens up new ethical questions related to translation quality assessment and the translator's professional status. The conventional binary such as professional vs. volunteer translator becomes easily disrupted when juxtaposing fansubbing, in the sense of nonprofessional subtitling performed by fans of the TV series or the movie, and 'classic' audiovisual translation. Moreover, with these new developments in TS as a consequence of the technological turn and the ubiquitous localization processes, translation tends to be seen by the translation industry as a subordinate hyponym to localization (Munday 2016). A detrimental relationship between translation and localization is also voiced by Chesterman who considers localization as a 'rebranding concept' "show[ing] how the notion of translation can be downgraded to a small corner of a rebranded larger practice, in order to highlight something presented as radically new, for commercial reasons" (Chesterman 2019: 18).

Tracing the wealth of possible sources of present-day polydisciplinarity in TS, the 'economic turn' (Gambier 2014, Bednárová-Gibová 2018) cannot go unmentioned when focusing on the proverbial propellers of future TS research scenarios. This new vocational orientation in TS stems from an exigent need to fuse TS and business studies in order to ensure a survival of the translation and interpreting studies graduates on the contemporary translation market which has become strictly business-oriented: translation skills and the knowledge of CAT tools seem important, but so is that of costs, modes of payment, clients, setting up one's licensed trade. 
To sum up, all (inward) turns, twists, tendencies or trends (whatever one's onomatological preference) lead to the expanding boundaries of the meta-discipline of TS on the cusp of the 2020s as a result of the ever progressing assimilation of myriad impacting agents and factors. According to Brems, Meylaerts and van Doorslaer, this unprecedented development over the past decade or two may have caused on the one hand that TS "is caught in a more or less permanent state of doubt or uncertainty" (Brems, Meylaerts and van Doorslaer 2014: 1). On the other hand, they somewhat ambivalently admit that this state of affairs could be considered by some as "signs of the dynamics of the discipline" (ibid.) Be that as it may, what is beyond doubt self-evident is that TS has reached a pausing place in its life cycle and the discipline per se calls for a meta-reflection on its potentials and caveats, as unfolding on the following pages.

\section{Consequences of polydisciplinarity: potentials and caveats}

The universal law of cause and effect says that for every cause there is a definite effect (and vice versa). So the effect of the extensive level of the polydisciplinarity in TS, as outlined in section 3, can make us pause for a while and think about how to react to it. Although polydisciplinarity has for long resonated with a zeitgeist in academia and many would argue that TS has always had some elements of this as "the Phoenician trader among longer-established disciplines" (Munday 2016: 25), the present-day inundation of possible directions and streams seems overwhelming. Thus, two natural reactions come to my mind: to ponder over whether TS should fight against the expanding boundaries of the field by focusing on its epistemological core, i.e. interlingual translation ${ }^{1}$, through a selected paradigmatic lens, or should it embrace the new developments in the sense of proactive and reciprocal interdisciplinarity? This question presents the first intradisciplinary tension, resulting from the polydisciplinarity of TS, which merits further discussion below.

Despite the limitations of the traditional paradigm of equivalence and the reframing of translation as an intercultural event (via the cultural turn) or a purposeful action (through the skopos theory), its application still resonates in today's translation practice, as acknowledged by Gambier (2016). My impression is that the theorists who advocate leaning on to interlingual translation, or translation proper, in Jakobson's words (1959/2012), hence supporting the equivalence paradigm, act as if they were under the influence of the fuzzy meaning hypothesis (as occurring in lexical semantics) since they voice their doubts about unclear conceptual borders and overlaps with other fields (cf. also van Doorslaer 2019). On the other hand, those in favour of proactive interdisciplinarity could be accused of superficiality, using outdated methods and concepts. For example, when promoting affective TS, you could easily come in for criticism that you are not a

${ }^{1}$ Interlingual translation in the sense of transfer from a source language into a target language has always been at the heart of (the text-centric) TS, thus representing its epistemological core. 
psychologist, as my own anectodal evidence suggests. Not too long ago, I approached a distinguished professor of psychology, who must not be named, at my home university, asking for collaboration for the purpose of a potential research grant, and he immediately flatly refused. In this way, the dreams about a fruitful academic cooperation were marred in the twinkling of an eye. This little anectodal digression, however, makes an important point to take heed of. Chesterman's solution (2007) to the problem of malfunctioning interdisciplinarity allegedly rests in collaborative work with experts in other fields, promoting what he dubs 'consilience', that is, the linking together of principles from different disciplines in order to create "the unity of all knowledge" (Chesterman 2007: 180). Although his suggestion clearly advocates academic disciplinary synthesis and interaction, sometimes even repackaged under a trendy catch-all name of transdisciplinarity ${ }^{2}$, consilience may be prevented from happening owing to harboured prejudices of prospective collaborators from other fields towards TS. As in our case, this primarily concerns the individuals who, in a (neo-)Catfordian manner, claim that TS should safely stick to its textual core, thus not keeping abreast of its postlinguistic stages emphasizing "connections between text, context and myriad agents" (Gambier 2016: 890).

A similar view on the effective collaboration sides is taken by Gentzler (2003) when he wisely argues that interdisciplinarity must be grounded on the principle of mutuality. This forms a certain parallel to what Kaindl (1999) calls 'reciprocal interdisciplinarity', surpassing both 'imperialistic interdisciplinarity', necessary for the development of the other discipline as well as 'importing interdisciplinarity', which TS as an interdiscipline has generally achieved (Göpferich 2011). Amidst this danger of interdisciplinarity, Gentzler (2003) forewarns us against 'easy appropriation' of TS concepts and reminds us that just as TS scholars have followed the omnipresent 'interdisciplinary turn', experts from other fields should advocate the 'translation turn' within their expertise, too. In my view, despite Gentzler's visions and advice, this mutual collaboration between TS and its prospective partners has not fully happened yet, or when it is happening, it is still far from being perfect. The problem is that there are TS scholars who audaciously claim that they

${ }^{2}$ My own stance towards the interdisciplinarity vs. transdisciplinarity pretentious prefix play has been to a substantial degree influenced by Chesterman's (2019) provocative paper in which he criticizes the risky rhetoric of proposed conceptual innovations across TS. Similarly, Brems, Meylaerts and van Doorslaer (2014: 5) also admit that 'interdisciplinarity' can be "clustered with multi-, trans- and pluridisciplinarity". It should be pointed out, though, that a different stance has been adopted by e.g. Massey (2020) who thinks that trandisciplinarity, with its action research going beyond disciplinary items of knowledge and its special focus on communities of practice targeted at real-world issues, is not synonymically equivalent to interdisciplinarity. According to Göpferich (2011), drawing on Kaindl's idea that transdiciplinarity stands for the closest form of collaboration between disciplines and could be roughly synonymous to what he labels as 'reciprocal interdisciplinarity', transdisciplinarity still has some way to go before it can be achieved in TS. Göpferich (ibid.) also cautiously admits that transdisciplinarity may never be fully materialized. Considering Kaindl's (1999) degrees or rather, stages of interdisciplinarity and evaluating the success of their accomplishment, Göpferich's scepticism still seems relevant today. 
are pursuing what they call "interdisciplinary TS research", integrating concepts and methodologies from other fields; but sticking to their one-sided borrowing they fail to explain how this conceptual-methodological transplantation enriches TS, and what TS can do in return for the donor disciplines. This suggests that a functional two-way conversation is needed between the prospective disciplines entering a possible collaboration. Not so long ago, there was some concern about the state of TS and its incapability to have a whole lot of impact on other disciplines, expressed by Bassnett and Pym (2017) in their joint critical article.

Moreover, interdisciplinarity in TS is seen as a threat by Daniel Gile who contends that it "adds to the spread of paradigms and may, therefore weaken further the status of [translation research] and [interpreting research] as autonomous disciplines" (Gile 2004 in Munday 2016: 26). Indeed, it must be admitted that TS at the outset of the 2020s is still much less academically institutionalized, at least in the Central European academic space, than some other disciplines it has obvious links with, although considerable progress has been made in this respect over the last decade-and-a-half. Hence, in order to preclude the dilution of the status of TS, it is necessary to ensure proactive and reciprocal interdisciplinarity based on Gentzler's principle of mutuality.

In view of the preceding discussion in relation to the forms of collaboration across disciplines, the following needs to be stressed in order to shed more light on the idea of useful progress in TS. Historically, not only TS but many disciplines have freely made use of what other fields of study have had to offer - and this has often been highly fruitful and much of the time delighted the disciplines from which the taking over took place. Some disciplines such as applied mathematics deliberately create tools like statistics for empirical sciences to use. Other disciplines, e.g. history, following the Annales school of history in France nearly a century ago, just borrowed freely from the humanities and social sciences and built insights from them into their own methodologies in ways which have since in history in many countries become usual and even normal. In this light, it might be useful to add that much current thinking about research in general sees collaboration across disciplines, institutions and nations as highly desirable. Hence, there are quite concrete as well as methodological reasons to believe that forms of collaboration seem an appropriate way forward for TS.

The second intradisciplinary tension has an extra-disciplinary outreach. Having the two, at first sight almost irreconcilable, worlds of academia and language industry in mind, there is a palpable tension between them in the light of TS's polydisciplinarity. Whereas our metaphorical 'Ivory Tower' often problematizes translation as an ever-expanding and definitely not ready-made concept in the aftermath of the TS's (inward) turns, outside academia, paradoxically, a 'reductionist view of translation' (van Doorslaer 2019) as a mere product of translation technology, such as Google Translate, persists. Despite the key players here being TS academics and/or practising translators, this forms, unfortunately, a mainstream view of translation because of its ubiquitous perception 
in everyday life. However untrue this may be considering the need for a human touch by translator, from a sociological perspective, such a depreciating interpretation of translation practices does obvious harm to the perception of the translator's status.

Another issue in my proverbial quest for the tensions induced by TS's polydisciplinarity is that while its outer boundaries are gradually expanding (as witnessed in the aftermath of its turns and orientations), the inner boundaries are becoming more and more blurred. Hand in hand with the 'digital paradigm' (Gambier 2016) resulting from the change of the platforms and media through which translational action is delivered, there is an upsurge in new names for translational activities. Fansubbing, cislation ${ }^{3}$ (Grbic 2013), scanlation, wikitranslation, to name just a few, all testify to this tendency. In addition, as Chesterman (2019) maintains, some TS concepts may undergo rebranding in the sense of acquiring a new signifiant applied to an extant concept, thus altering connotations, mostly for commercial reasons (e.g. in the case of localization or transcreation). Another evidence of the tendency that the inner boundaries of the TS are being erased is for example the fact that nowadays we cease to discriminate sharply between the, previously firmly established, literary and non-literary translation binary as a result of its reconceptualization as border due to productive intersections between the two (Rogers 2019).

Fourthly, seen through didactic lenses, TS as a field of study has grown exponentially around the world and in terms of study programmes all over Europe. As a result of this concentric spread, there seems to be a multitude of different interpretations of what TS should cover and how it should be conceptualized. The multitude of interpretations is, however, not necessarily a bad thing. On the contrary, many other disciplines, e.g. philosophy or history, have a similar variety of approaches and interpretations and many would see this as enriching to the discipline. The first hints at a drift among academics, and the subsequent need for a clarification on the shared ground of TS, have been given already by Chesterman and Arrojo (2000) in their provoking debate. One end of their spectrum of evaluations takes us to the perspective of postmodernist cultural studies and textual theories, while the other one to that of empirical and descriptive science. They aptly observe that the controversy between these opposing approaches can be resolved in terms of essentialism and non-essentialism (ibid.).

Be that as it may, seeking progressive ideas almost two decades later, some scholars report that they would welcome it if translation in the next decade could be sensitively integrated into studies transcending the humanities, including law, medicine and business (Bassnett and Pym 2017), thus perhaps overcoming its long lamented crisis. A tantalizing question that looms large is whether TS should be

3 "I suggest the term cislation, meaning carrying the reader - not the text - hither, cis, into the world inhabited by the particular work in question" (Grbic 2013: 775). As follows from the quotation, cislation refers to transporting the reader into the culture of the original, i.e. the source culture. 
more practice-oriented in compliance with the requirements of the present-day language industry or, conversely, more abstract in order to uphold the conventional spirit of academia? ${ }^{4}$ The question also expresses the need to think more about the balance and relation of practice and theory in contemporary university courses. The dichotomy of possible treatments with regard to this schism also seems to be a direct consequence of the persisting lack of the institutionalization of TS. In addition, some could argue that this is academic freedom and a form of contextual localization which is to be welcomed and not eliminated. The increased focus on practice has also been highlighted within a complex accreditation process that many European universities, including Slovakia, are currently going through. However, if TS as an academic field of study were to become even more practice-oriented, in compliance with the demands of the translation market, a question then arises to what extent academia should be allowed to be manipulated by these external pressures? And perhaps more importantly, who has the prerogative to dictate the future course of the development of TS? Is it translation market or academia? Amidst this clash of paradigmatic approaches, I take a moderate view and thus call for striking a healthy balance between overtheorizing and a too strong focus on practice. My misgiving is that if TS should be relegated to a purely practical branch of study because of the pressing need to respond to demands, not only does it risk the danger of losing its hard fought position in the academic environment, but harm could also be done to its cultural, cognitive, deconstructivist, and philosophical legacy whose strands have for long permeated the gnozeological core of the multidiscipline in point. Jean Boase-Beier, for example, supports the usefulness of theory for translators seeing it as "a creatively constructed (and shifting) view of practice" (Boase-Beier 2006: 48). This implies that informed theory of translation can help practice to become more thought through, less haphazard and intuitive, as a result of translators' more complex approach to a translatum involving a wide array of extratextual and intratextual factors (cf. Nord 2005).

One way or another, the somewhat artificial and at times even unclear divide between theory and practice has been worsened by sceptical practitioners of translation themselves who consider translation theory forbidding, failing to acknowledge its connection with practice (Wright 2016). Unfortunately, the dialectic relationship between theory and practice is also reflected in the formal assessment of research and publishing activities, at least in the Slovak academic setting, where scholarly papers, and those in top tier journals in particular, are

\footnotetext{
${ }^{4}$ It should be stressed that by treating the theory versus practice dichotomy, it is my intention neither to pigeonhole nor oversimplify the range of writings within TS and the range of orientations of university degrees in TS across a whole variety of national and cultural settings. While many writings seem highly theoretical (e.g. Friedrich Schleiermacher, Anton Popovič, Jiří Levý or Lawrence Venuti to some extent), many important figures in the discipline (e.g. Mona Baker, Jeremy Munday, Ritva Leppihalme) are in many ways practice-oriented, all going to constitute what is termed TS. It is also the case that is often perfectly possible to work one's way through what theoretical writings imply for reflective translation practice, and to further work through what this might imply for pedagogy.
} 
valued much higher than book-length translations ${ }^{5}$. This obviously undermines the value of the practice of translation, as if creating forced separation between the two discussed ends of the spectrum.

\section{So what now or future directions of TS}

As we have seen in section 3, the inward turns in TS are based on its interdisciplinarity. The major problem with the interdisciplinarity of TS has been that although it has taken much from other disciplines, it has been less successful in terms of giving back. For this reason, it is now high time for TS to step forward, and most importantly, outward ${ }^{6}$. In this connection, Zwischenberger (2019) demands that TS should perform two 'outward turns' in the foreseeable future. First, to step outside its box and show its relevance to and impact on other disciplines and second, to bridge the gap between TS and translation practice and foster affinity between them (ibid.).

With a view to the first outward turn, it should be stressed that if TS fails to show its relevance to other disciplines ${ }^{7}$, it is likely to be downplayed by them since their dominance over what constitutes translation is becoming prominent, as Zwischenberger admits (ibid.). As to the second outward turn, current trends imply that the need for the link with translation practice has been gaining momentum, now more than ever. Although the interlacement with practice has been a major weakness of TS, especially in contrast to hard sciences disciplines, it is important not to lapse into one-sided practical orientation, which surely has its drawbacks, as already implied in section 4. For this reason, it is not only desirable, but also necessary to seek a constructive relationship between theory and practice.

Moving onwards, assimilating all formative influences on the shaping of TS via its inward and now also outward turns, a question could be posed why we translate in a particular manner and how novel ideas are imported to cultures through translation (Liu and Wen 2018). Following Bassnett's and Lefevere's (1990) cultural turn, and the more recent sociological turn (Wolf and Fukari 2007), Gentzler (2017) gives an answer in his pioneering work "Translation and Rewriting in the Age of Post-Translation Studies" and invites TS to embark on a new stage, initiating a 'post-translation turn'. He proposes two directions of post-translation studies focusing on socio-political and linguistic conditions of pre-translation culture, i.e. "the initial reception of the translated text" (Gentzler 2017: 3) involving an analysis of pre-textual elements, and post-translation effects, that is "repercussions generated in the receiving culture over subsequent years" (ibid.) going beyond the text-centric. Besides, post-TS examines intralingual translation

${ }^{5}$ For comparison's sake, similar evaluations of research activities in the UK, downgrading translations, have been reported by e.g. Munday (2016).

${ }^{6}$ It should not be forgotten, though, that in those domains where TS has become closely interlaced with intercultural studies, this has happened already very extensively.

${ }^{7}$ The need for TS to 'look outwards', that is to reach out to other disciplines in the wake of a translational turn in the humanities, has also been promoted by Bassnett (2014). 
and intersemiotic renderings such as musical, cinematic, or other media versions of the original, taking into account new genres spawned by new media. In liaison with crucial postmodernist concepts of simulacrum, in the sense of the copy without original, and simulation (Baudrillard 1981/1994), and echoing Lefevere's (1992) idea of translation as a form of rewriting, Gentzler suggests that "all writing is rewriting, or a rewriting of a rewriting and translation - intralingual, interlingual, intersemiotic" (Gentzler 2017: 10). In this way, there are fine lines between original, translation and rewriting, and it makes no sense anymore to attempt to discriminate between them (Bassnett 2017: ix).

In the effort to pinpoint a further direction of TS in the near future, an emerging transdisciplinary paradigm could be felt inspiring for research. In this connection, Massey (2020) emphasizes the idea that it is a transition from interdisciplinarity to transdisciplinarity that TS is currently making and must continue to make with its focus on life-world problems, participant-oriented research, overcoming strands of isolated disciplinary paradigm in order to serve the realities of translation in the community of practice, and organizations (cf. Bednárová-Gibová 2021) where translation takes place. Thus, a transdisciplinary course of investigation makes another potent example of the future direction of TS in order to ensure its viability. While Massey's approach is more work-place-oriented, explored through cognitive, ergonomic and organizational lenses, the earlier treatment of transdiciplinarity by e.g. Odacioğlu and Köktürk (2015) centres on the integration of ICT, CAT-tools, translation memories and localization into TS, thus invoking its digital aspects.

All in all, considering the current development within TS as a meta-discipline and the tensions discussed in the light of its polydisciplinarity, an attempt has been made of late to provide a hyperonym encompassing all TS's bewildering courses of action, intimating its inter- and transdiciplinarity: trans-studies (cf. van Doorslaer 2019). Although this radical proposal at the onomatological level does not seem to have caught on, perhaps also due to potential links with transgender or transport issues, as van Doorslaer (ibid.) himself admits, an attempt like this only prefigures more possible changes, which are bound to happen in TS any time soon.

\section{Conclusion}

By way of summing up, it should be reiterated that what emanates from a critical look at the present state of TS as a multidiscipline by means of reflexive introspection, is a need to ponder over its potentials as well as caveats induced by its possible paths of the development, as sketched in this paper. As its thematic axes have shown, the con of the TS's inward turns has been its ever-progressing diffusion; TS seems to have lost an equilibrium between the healthy need for a polydisciplinary plurality of embraced perspectives and the likelihood of diffusion. Another downside to transdisciplinary TS, as also epitomized by post-translation studies, is the issue of how much constructive conversation and mutually enriching relationship there really exists between TS and its potential partners? While the outer boundaries of TS have been stretched to the utmost, much broader 
interpretations of translation have come its way, which has problematized the concept of translation. Following the outward turns of TS, further transcending of its self-imposed boundaries can surely be expected by "greater exchanges with other disciplines in a mutually beneficial process of importing and exporting methodologies and ideas", as Bassnett (2017: ix-x) predicts. In the light of continuing theoretical reflection and empirical practice in the foreseeable future, I suggest that we rethink the mutual cooperation between these two opposing sides of the spectrum as imperative, also in tune with the current trend of popularization of science and the transdisciplinary need for researching real-world issues. Subsequently, the enriching interaction between theory and practice ought to be wisely incorporated into the $21^{\text {st }}$ century translator training to make TS a really viable field of study, not hampered by the weaknesses of its interdisciplinarity.

(C) Klaudia Bednárová-Gibová, 2021
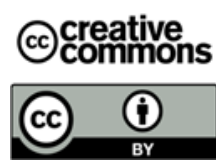

This work is licensed under a Creative Commons Attribution 4.0 International License https://creativecommons.org/licenses/by/4.0/

\section{REFERENCES}

Bassnett, Susan. 2014. Translation studies at a cross-roads. In Elke Brems, Reine Meylaerts \& Luc van Doorslaer (eds.), The Known Unknowns of Translation Studies, 17-27. Amsterdam/Philadelphia: John Benjamins.

Bassnett, Susan. 2017. Foreword. In Edwin Gentzler (eds.), Translation and Rewriting in the Age of Post-Translation Studies, viii-x. London/New York: Routledge.

Bassnett, Susan \& André Lefevere. 1990. Translation, History and Culture. London/New York: Pinter Publishers.

Bassnett, Susan \& Anthony Pym. 2017. On the direction of Translation Studies. Cultus: the Journal of Intercultural Mediation and Communication 10 (1). 145-152.

Bednárová-Gibová, Klaudia. 2018. More recent avenues of research in contemporary translation studies. In Lucyna Harmon and Dorota Osuchowska (eds.), Translation Studies across the Boundaries, 15-30. Berlin: Peter Lang.

Bednárová-Gibová, Klaudia. 2021. Organizational ergonomics of translation as a powerful predictor of translators' happiness at work? Perspectives: Studies in Translation Theory and Practice 29 (3). 391-406. DOI: https://doi.org/10.1080/0907676X.2020.1753788

Boase-Beier, Jean. 2006. Loosening the grip of the text: Theory as an aid to creativity. In Manuela Perteghella \& Eugenia Loffredo (eds.), Translation and Creativity. Perspectives on Creative Writing and Translation Studies, 47-56. London/New York: Continuum.

Brems, Elke, Reine Meylaerts \& Luc van Doorslaer. 2014. Translation studies looking back and looking forward. A discipline's meta-reflection. In Elke Brems, Reine Meylaerts \& Luc van Doorslaer (eds.), The Known Unknowns of Translation Studies, 1-16. Amsterdam/Philadelphia: John Benjamins.

Cronin, Michael. 2010. The translation crowd. Revista Tradumàtica: tecnologies de la traducció 8. 1-7. DOI: https://doi.org/10.5565/rev/tradumatica.100 
Chesterman, Andrew \& Rosemary Arrojo. 2000. Shared ground in translation studies. Target 12 (1). 151-160. DOI: https://doi.org/10.1075/target.12.1.08che

Chesterman, Andrew. 2007. Bridge concepts in translation sociology. In Michaela Wolf \& Alexandra Fukari (eds.), Constructing a Sociology of Translation, 171-183. Amsterdam/Philadelphia: John Benjamins.

Chesterman, Andrew. 2019. Moving conceptual boundaries: so what? In Helle V. Dam, Matilde Nisbeth Brogger \& Karen Korning Zethsen (eds.), Moving Boundaries in Translation Studies, 12-25. London/New York: Routledge.

El-dali, Hosni Mostafa. 2011. Towards an understanding of the distinctive nature of translation studies. Journal of King Saud University - Languages and Translation 23 (1). 29-45. DOI: https://doi.org/10.1016/j.jksult.2010.01.001

Gambier, Yves. 2014. Changing landscape in translation. International Journal of Society, Culture \& Language 2 (2). 1-12.

Gambier, Yves. 2016. Rapid and radical changes in translation and translation studies. International Journal of Communication 10. 887-906. https://ijoc.org/index.php/ijoc/ article/view/3824 (accessed 18 November 2020).

Gentzler, Edwin. 2003. Interdisciplinary connections. Perspectives 11 (1). 11-24. DOI: https://doi.org/10.1080/0907676X.2003.9961458

Gentzler, Edwin. 2017. Translation and Rewriting in the Age of Post-Translation Studies. New York: Routledge.

Göpferich, Susanne. 2011. From multidisciplinarity to transdisciplinarity: The investigation of competence development as a case in point. In MikaEL electronic proceedings of the KäTu Symposium on Translation and Interpreting Studies 5, 1-24. http://www.sktl.fi/@Bin/ 85366/Gopferich_MikaEL2011.pdf (accessed 21 December 2020).

Grbić, Igor. 2013. Translation vs. cislation: should the reader be pampered or challenged? In

Ivana Živančević Sekeruš (eds.), Sixth International Interdisciplinary Symposium Meeting of Cultures 2. 773-780. Novi Sad: University of Novi Sad, Faculty of Philosophy.

Holmes, James. 1988/2004. The name and nature of translation studies. In Lawrence Venuti (eds.), The Translation Studies Reader. 2nd edn., 180-192. London/New York: Routledge. Jakobson, Roman. 1959/2012. On linguistic aspects of translation. In Lawrence Venuti (eds.), The Translation Studies Reader. 3rd edn., 126-131. London/New York: Routledge.

Kaindl, Klaus. 1999. Interdisziplinarität in der Translationswissenschaft: Theoretische und methodische Implikationen. In Alberto Gil, Johann Haller, Erich Steiner and Heidrun

Gerzymisch-Arbogast (eds.), Modelle der Translation: Grundlagen für Methodik, Bewertung, Computermodellierung, 137-155. Frankfurt am Main: Peter Lang.

Leech, Geoffrey \& Mike Short. 1981/2007. Style in Fiction: A Linguistic Introduction to English Fictional Prose. London: Longman.

Leech, Geoffrey. 2008. Language in Literature: Style and Foregrounding. London: Routledge. Lefevere, André. 1992. Translation, Rewriting and Manipulation of Literary Fame. London/ New York: Routledge.

Liu, Jinhui \& Jun Wen. 2018. Review of [Gentzler, Edwin (2017). Translation and Rewriting in the Age of Post-Translation Studies. New York: Routledge]. Meta 63 (1). 267-269. DOI: https://doi.org/10.7202/1050530ar

Munday, Jeremy. 2016. Introducing Translation Studies. 4th edn. London: Routledge.

Nord, Christiane. 2005. Text Analysis in Translation: Theory, Methodology and Didactic Application of a Model for Translation-oriented Text Analysis. 2nd edn. Amsterdam: Rodopi.

Odacioğlu, Mehmed Cem \& Şaban Köktürk. 2015. From interdisciplinarity to transdisciplinarity in translation studies in the context of technological tools \& localization industry. International Journal of Comparative Literature \& Translation Studies 3 (3). 
14-19. https://www.journals.aiac.org.au/index.php/IJCLTS/article/view/1648 (accessed 21 December 2020).

Rogers, Margaret. 2019. From binaries to borders. In Helle V. Dam, Matilde Nisbeth Broqgger \& Karen Korning Zethsen (eds.), Moving Boundaries in Translation Studies, 151-167. London/New York: Routledge.

Sdobnikov, Vadim V. 2019. Translation studies today: Old problems and new challenges. Russian Journal of Linguistics 23 (2). 295-327. DOI: https://doi.org/10.22363/23129182-2019-23-2-295-327.

Shadman, Nazanin, Masood Khoshsaligheh \& Reza Pishghadam. 2019. Iranian literary translators' emotional intelligence: Description of facets. SKASE Journal of Translation and Interpretation 12 (1). 29-47. http://www.skase.sk/Volumes/JTI16/pdf_doc/03.pdf (accessed 18 November 2020).

Snell-Hornby, Mary. 1988/1995. Translation Studies: An Integrated Approach. Amsterdam/ Philadelphia: John Benjamins.

Snell-Hornby, Mary. 2006. The Turns of Translation Studies. New Paradigms or Shifting Viewpoints? Amsterdam//Philadelphia: John Benjamins.

van Doorslaer, Luc. 2019. Bound to expand. The paradigm of change in translation studies. In Helle V. Dam, Matilde Nisbeth Broggger \& Karen Korning Zethsen (eds.), Moving Boundaries in Translation Studies, 220-230. London/New York: Routledge.

Wolf, Michaela \& Alexandra Fukari (eds.). 2007. Constructing a Sociology of Translation. Amsterdam/Philadelphia: John Benjamins.

Wolf, Michaela. 2014. The sociology of translation and its 'activist turn'. In Claudia Angelelli (eds.), The Sociological Turn in Translation and Interpreting Studies, 7-21. Amsterdam/ Philadelphia: John Benjamins.

Wolf, Michaela. 2017. A "performative turn" in translation studies? Reflections from a sociological perspective. Transcultural 9 (1). 27-44.

Wing-Kwong Leung, Matthew. 2006. The ideological turn in translation studies. In João Ferreira Duarte, Alexandra Assis Rosa \& Teresa Seruya (eds.), Translation Studies at the Interface of Disciplines, 129-144. Amsterdam/Philadelphia: John Benjamins.

Wright, Chantall. 2016. Literary Translation. London/New York: Routledge.

Zwischenberger, Cornelia. 2019. From inward to outward: the need for translation studies to become outward-going. The Translator 25 (3). 256-268. DOI: https://doi.org/10.1080/ 13556509.2019.1654060

\section{Internet resources}

Baudrillard, Jean. 1981/1994. Simulacra and Simulation [online]. Ann Arbor, MI: University of Michigan Press. DOI: https://doi.org/10.3998/mpub.9904 (accessed 9 November 2020).

Massey, Gary. 2020. Moving from interdisciplinarity to transdisciplinarity: Research in translation studies. A talk given at the QS Subject Focus Summit-Modern Languages \& Linguistics: Languages and Migration in a Globalized World on December 15, 2020, https://qssubjectfocus.com/moscow-2020/speakers (accessed 21 December 2020).

\section{Article history:}

Received: 16 January 2021

Accepted: 28 March 2021

\section{История статьи:}

Дата поступления в редакцию: 16 января 2021

Дата принятия к печати: 28 марта 2021 


\section{Bionote:}

Klaudia BEDNÁROVÁ-GIBOVÁ is an Associate Professor of Translation Studies at the Institute of British and American Studies at the University of Presov in Slovakia. She is a zealous lecturer, translation studies enthusiast and a professional translator of specialized texts working from/into English and German. Her main fields of research comprise legal translation, institutional translation, contrastive linguistics terminology, and the sociology of translation. More recently, she has taken a keen interest in psycho-translation studies with a particular focus on the affectivity of translator behaviour. Her recent work has been published, among others, in leading translation studies journals such as Meta, Perspectives, The Translator and Translation Studies.

\section{Contact information:}

University of Presov, Presov, Slovak Republic

e-mail:klaudia.gibova@unipo.sk,klaudia.gibova@gmail.com

ORCID: 0000-0002-6555-4464

\section{Сведения об авторе:}

Клаудиа БЕДНАРОВА-ГИБОВА - доцент отделения переводоведения Института британских и американских исследований, Университет Прешов, Словакия. Она активно занимается переводоведением, является профессиональным переводчиком специальных текстов с английского языка на немецкий и наоборот. Основная область исследований включает юридический перевод, институциональный (официальный) перевод, контрастивное изучение лингвистической терминологии и социологии перевода. Недавно она начала заниматься проблемами психологии перевода, в особенности аффективностью поведения переводчика. Ряд ее работ опубликован в ведущих переводоведческих журналах, таких как Meta, Perspectives, The Translator и Translation Studies.

\section{Контактная информация:}

University of Presov, Presov, Slovak Republic e-mail: klaudia.gibova@unipo.sk,klaudia.gibova@gmail.com

ORCID: 0000-0002-6555-4464 